\title{
The Effect of Flipbook Media on Visual Students' Learning Outcome in Remedial Teaching of Parabolic Motion Concept
}

\author{
Iwan Permana Suwarna ${ }^{1}$, Dini Nurhayati ${ }^{2}$ \\ \{iwan.permana.suwarna@uinjkt.ac.id ${ }^{1}$,dini.nurhayati14@mhs.uinjkt.ac.id² $\}$ \\ UIN Syarif Hidayatullah Jakarta, Indonesia ${ }^{1,2}$
}

\begin{abstract}
Physics remedial teaching in Indonesian High School (SMA) does not accommodate the diversity of student learning styles. That has an impact on low student learning outcomes (cognitive domain of Bloom's taxonomy $\mathrm{C} 2-\mathrm{C} 4$ ). This research was conducted at SMA in South Tangerang Banten on November 2018 with a sample of 20 visual students. The sample was selected by purposive technique, from 188 students (tenth-grade natural sciences). Samples were divided into two groups (experiment and control) with the same amount. The results of hypothesis testing (Mann-Whitney test) obtained sig values. $0.040(\alpha=0.05)$, concluded that alternative hypothesis was accepted. There was an influence of flipbook media on visual students' learning outcome in remedial teaching of parabolic motion concept. Students in experimental group experienced a high increase in $\mathrm{C} 4$ (analyse) with an $\mathrm{N}$-gain of 0.73 . The flipbook is very effective (80\%). It helps process of remedial learning and accommodate students.
\end{abstract}

Keywords: Flipbook Media, Remedial Teaching, Parabolic Motion, Learning Outcomes, Visual students.

\section{Introduction}

The average results of the Indonesian National Examination in physics at the South Tangerang Senior High School (SMA) have decreased in the last three years. The average decline in the value of the 2015-2017 physics National Examination was 25.90\% (73.07 to 54.15), 5.53\% (54.5 to 51.15) [1]. Decreasing the average value of the National Examination is one of the impacts of physics learning that has not been optimal. Students have different learning difficulties. One reason is the difference in students' understanding of the stimulus provided by the teacher, due to differences in learning styles [2]. Students who have learning difficulties and cannot maximize their abilities continue while they are participating in remedial activities by the teacher. However, at this time the teacher does not provide special treatment or remedial learning to students who have not yet completed/have difficulty in learning.

The handling of the remedial learning process carried out by the teacher has not been done ideally. These problems include: First, $58.43 \%$ of students said the teacher did remedial activities through written tests [3]. In the parabolic motion material, the number of students who completed the State High School in South Tangerang was 343 students (72.36\%) [3]. In theory, if the number of remedial students reaches $50 \%$, the form of remedial learning that must be done is remedial teaching [4]; Second, remedial student learning outcomes are still 
incomplete. On average students take three remedial tests to get completeness scores [3]; Third, students have difficulty in visualizing the motion displacement trajectory after being given the initial angle, students cannot predict the farthest distance on the trajectory of objects with different angles [5], and students find it difficult to determine the quantities of parabolic motion (difficult to distinguish the use of formulas) [3]; Fourth, the lack of interaction and guidance by the teacher (learning is still teacher-centered). Learning by teachers is still classical and conventional [3]; Fifth, the teacher does not realize that students have different learning styles; Sixth, the display of books used by students to learn the concept of parabolic motion is less interesting because it only contains formulas and explanations that are abstract. The material does not display a lot of pictures and animations/videos that relate the concept to everyday life. The problem causes the visual students are not optimal in understanding the concept of parabolic motion. Visual students have difficulty in understanding the concepts that require explanation in the form of graphic images, vectors and real examples in everyday life [6]; seventh, most visual students do not complete the concept of parabolic motion (81\%); and eighth, teachers only provide one learning stimulus (learning style), students with different learning styles have difficulty in understanding the concepts [2].

Remedial teaching-learning for visual students on the concept of parabolic motion is very important to do. If remedial teaching is not carried out then, the value obtained by visual students will remain low or no different from previous grades that are not completed; understanding of remedial learning concepts will not increase; the concept of parabolic motion is important for students to understand because this concept always appears in every National Examination; visual students have difficulty in accepting the information conveyed by the teacher, and students cannot understand their learning styles and develop learning attitudes and habits to get better results.

Visual students' learning outcomes that follow the remedial on the concept of parabolic motion can be improved if they are given remedial teaching-learning by using flipbook media. Remedial teaching-learning can help students to understand the material more closely related to the material being studied. Improved understanding of students who learn with flipbook media on the concept of parabolic motion can improve student learning completeness. The visual students who learn to use flipbook media can visualize the abstract concept of parabolic motion into the concrete. Flipbook media can visualize the concept of parabolic motion such as movements in the field of sports (soccer, basketball, volleyball, and javelin throwing), military (putting down bullets/bombs in cannons), and homework (watering plants with a hose). Flipbook media can be inserted by animation that supports learning the material in the form of video or flash animation, student-centered oriented, can be opened at any time, and can be opened on all computers/laptops even though the flipbook application is not installed [7]. With the advantages of flipbook media, it is expected to help students to maximize their learning abilities following their visual learning styles to achieve learning mastery. This study aims to determine the effect of flipbook media on visual students' learning outcome of parabolic motion concept. 


\section{Materials and Method}

\subsection{Setting and Subjects}

The research method used in this study was a quasi-experimental method with the Nonequivalent Control Group Design [7]. The population in this study was students of tenthgrade Senior High School in South Tangerang Banten odd semester 2018/2019 school year with a total of 188 students divided into five classes. The affordable population in this study amounted to 26 students. The sample used in this study amounted to 20 students who were divided into two groups, namely the experimental group and the control group. The sample was determined using a purposive sampling technique, with the criteria used in sample selection are groups of visual students who are incomplete on the concept of parabolic motion [8]. Both groups that were sampled given VARK (Visual Auditory Read-Write Kinesthetic) learning style tests to find out students who had visual learning styles. Both groups have also followed daily tests on the concept of parabolic motion, but the results are incomplete. The experimental group was given remedial teaching treatment using flipbook media while the control group was given remedial teaching treatment not using flipbook media.

\subsection{Data Collection}

Data collection in this study was carried out with two test instruments. First, all students from the population, were given the VARK learning style test instrument. This test was used to find out the learning styles students have. The VARK learning style test instrument consisted of 16 multiple choice questions with four answer choices according to the characteristics of visual, auditory, read-write, and kinesthetic learning styles [9]. Furthermore, the results of the VARK learning style test were used to determine the research sample, namely students who have a visual learning style.

Second, the data collection of student learning outcomes used the pre-test and post-test instruments consisting of 13 multiple choice questions with five answer choices. The pre-test and post-test test instrument consisted of C2, C3 and C4 cognitive domain of Bloom's Taxonomy. The instrument has been validated by 16 experts (physicists, construction experts, and linguists). The expert assessment results were processed using a content validity ratio (CVR) [10] which was then used to obtain a content validity index (CVI) value which is an average of the CVR value [10]. This test instrument has also been tested on 42 students. The reliability test results were in the high category $(0.88)$.

\subsection{Data Analysis}

The data obtained through the VARK learning style test instrument was then processed to determine the learning styles that each student has. This learning style test results produce four answer choices (Visual, Auditory, Read-Write, and Kinesthetic) with one score for each learning style. The score is then used to determine the learning styles students have based on the number of scores from one learning style that is more dominant than the others [9].

Data obtained through the pre-test and post-test test instruments were tested using the SPSS application [11]. The test given is the normality test using the Sapiro-Wilk test; homogeneity test using the Levene test; and hypothesis testing on pre-test data using the t-test, on post-test data using the Mann-Whitney test. To find out the increase in understanding or mastery of students' concepts after learning, the pre-test and post-test results were tested using 
the N-gain test [12]. Furthermore, the data was tested for effectiveness by looking at the percentage of students who get learning outcomes $\geq$ KKM (Kriteria Ketuntasan MinimalCriteria for minimum completion) after attending remedial teaching [13].

\subsection{Hypothesis}

The formulation of statistical hypothesis in this study was to test the differences in the average learning outcomes of remedial teaching in the experimental and control group is:

$$
\begin{aligned}
& \text { Ho: } \mu=\mu_{o} \\
& \text { Ha: } \mu \neq \mu_{\mathrm{o}}
\end{aligned}
$$

Explanation:

Ho = Null Hypothesis (there is no influence of flipbook media on remedial teaching on visual students learning outcomes)

$\mathrm{Ha}=$ Alternative Hypothesis (there is an influence of flipbook media on remedial teaching on visual students learning outcomes)

$\mu \quad=$ The average visual students learning outcomes on remedial teaching in the experimental group who were treated learning with flipbook media

$\mu_{0} \quad=$ The average visual students learning outcomes on remedial teaching in the control group who were treated learning didn't use flipbook media

\section{Result and Discussion}

The results of the VARK learning style test of 188 students with visual learning styles spread over five natural science tenth-grade in this study are shown in Table $\mathbf{1}$ below.

Table 1. VARK Learning Style Test Results

\begin{tabular}{ccc}
\hline No. & Learning Style & Percentage \\
\hline 1. & Visual & $9 \%$ \\
\hline 2. & Visual-Auditory & $2 \%$ \\
\hline 3. & Visual - Read-Write & $2 \%$ \\
\hline 4. & Visual - Kinesthetic & $1 \%$ \\
\hline 5. & Visual - Read-Write - Kinesthetic & $1 \%$ \\
\hline 6. & Auditory & $27 \%$ \\
\hline 7. & Read-Write & $25 \%$ \\
\hline 8. & Kinesthetic & $24 \%$ \\
\hline 9. & Read-Write - Kinesthetic & $3 \%$ \\
\hline 10. & Auditory - Read-Write & $4 \%$ \\
\hline 11. & Auditory - Read-Write - Kinesthetic & $1 \%$ \\
\hline
\end{tabular}

Based on the table 1, there are $14 \%$ (26) visual students spread across five classes of natural sciences. Then, a pre-test was given to students from the population who were spread out in the five classes of natural science in the form of daily tests conducted after learning with the teacher to determine student learning outcomes on the concept of parabolic motion. Pretest results stated student learning outcomes on the concept of parabolic motion is still low. $87 \%$ of students do not complete their learning outcome. The cause of the low student learning outcomes in the concept of parabolic motion is students do not understand the concept of parabolic motion-in-depth and students have difficulty to distinguish the use of formulas to solve problems because many formulas are used in the concept. Visual students who did not complete had to take remedial teaching. Students who did not complete were $>50 \%(80.7 \%)$. 
Visual students who are incomplete are divided into two groups with the same number of visual students (10 students), namely the experimental and control groups.

The recapitulation of students' pre-test and post-test results is presented in the following Table 2 .

Table 2. Pre-test, Post-test, N-gain, and Effectiveness Test of Visual Students' Learning Outcomes

\begin{tabular}{ccccc}
\hline \multirow{2}{*}{ Descriptive } & \multicolumn{2}{c}{ Control } & \multicolumn{2}{c}{ Experiment } \\
\cline { 2 - 5 } & Pre-test & Post-test & Pre-test & Post-test \\
\hline $\begin{array}{c}\text { Minimum } \\
\text { Score }\end{array}$ & 1,00 & 4,00 & 2,00 & 9,00 \\
\hline Maximum Score & 9,00 & 11,00 & 9,00 & 12,00 \\
\hline Mean & 5,30 & 8,80 & 4,90 & 10,30 \\
\hline Median & 5,50 & 9,00 & 5,00 & 10,00 \\
\hline Mode & 8,00 & 10,00 & 5,00 & 10,00 \\
\hline Standard Deviation & 2,58 & 1,93 & 2,47 & 1,06 \\
\hline N-gain & \multicolumn{3}{c}{0,4} \\
\hline N-gain Criteria & \multicolumn{3}{c}{ Medium } & \multicolumn{3}{c}{ Medium } \\
\hline Effectiveness & \multicolumn{2}{c}{$40 \%$} & \multicolumn{2}{c}{$80 \%$} \\
\hline Effectiveness Criteria & Not Effective & \multicolumn{3}{c}{ Very Effective }
\end{tabular}

The pre-test score of both classes was low and did not reach half of the maximum score (6.5 out of 13). The mean score' pre-test of the control class (5.30) was slightly higher than the experimental class (4.90). The reason for the low pre-test results of visual students is the conventional learning method where the learning process is centered on the teacher, students only see the material exposure on the blackboard, listen to the teacher's explanation, take notes, and memorize [3]. They find it difficult to understand the teacher's explanation with this method because they prioritize the important role of the eye as a vision so that it requires clear and concrete visualization to build understanding [14].

Post-test scores of both classes after being given remedial teaching treatment have increased. The mean score of the pre-test in the control group increased by $3.50(27 \%)$ from 5.30 to 8.80 in the post-test, while the mean score of the pre-test (mean) in the experimental group increased by $5.40(41.5 \%)$ from 4.90 to 10.30 at the post-test. The increase in the average pre-test score in the experimental group was greater than the control group. It means that the experimental group had higher learning outcomes than the control group. Improved learning outcomes can also be seen from the $\mathrm{N}$-gain of both groups. $\mathrm{N}$-gain in the experimental group was higher (0.7) compared to the control group (0.3).

The percentage of students' post-test completeness in the control group was $40 \%$, meaning that the treatment given to the control group was not effective in improving visual students' learning outcomes. Meanwhile, the percentage of post-test completeness in the experimental group was $80 \%$, which meant that the treatment given to the experimental group was very effective in improving visual students' learning outcomes. This states that flipbook media is effectively used in overcoming student learning difficulties [15].

Student learning outcomes in the experimental group are higher than the control group due to the use of flipbook media that facilitates visual students can maximize their ability to understand knowledge because learning is following their learning styles. 
The average $\mathrm{C} 2, \mathrm{C} 3$, and $\mathrm{C} 4$ cognitive domain scores and $\mathrm{N}$-gain of Bloom's taxonomy based on the results of the pre-test and post-test in the control and experimental groups can be seen in Table 3 below.

Table 3. Comparison of Average Score and N-gain of Control Group and Experiment Group

\begin{tabular}{ccccc}
\hline Group & Score & C2 & C3 & C4 \\
\hline \multirow{4}{*}{ Control } & Pre-test & 0.40 & 0.37 & 0.48 \\
\cline { 2 - 5 } & Post-test & 0,70 & 0.64 & 0.73 \\
\cline { 2 - 5 } & N-gain & 0.45 & -0.63 & 0.44 \\
\cline { 2 - 5 } & N-gain Criteria & Medium & Low & Medium \\
\cline { 2 - 5 } Experiment & Pre-test & 0.55 & 0.33 & 0.38 \\
\cline { 2 - 5 } & Post-test & 0.85 & 0.73 & 0.88 \\
\cline { 2 - 5 } & N-gain & 0.60 & 0.56 & 0.73 \\
\cline { 2 - 5 } & N-gain Criteria & Medium & Medium & High \\
\hline \multirow{2}{*}{$\begin{array}{c}\text { Maximum score of pre-test } \\
\text { post-test }\end{array}$} & 2.00 & 7.00 & \multirow{2}{*}{13.00} \\
\hline
\end{tabular}

The average score of the final abilities of cognitive domains C3 and C4 in the experimental group ( 0.73 and 0.88$)$ experienced a significant increase from their initial abilities $(0.33$ and 0.38). The difference between the average score of $\mathrm{C} 3$ and $\mathrm{C} 4$ cognitive abilities in the experimental group was higher than in the control group. This shows that there is a significant improvement after being given remedial teaching treatment using flipbook media in the experimental group. A comparison of the average pre-test and post-test scores of the control group and the experimental group is presented in Figure 1.

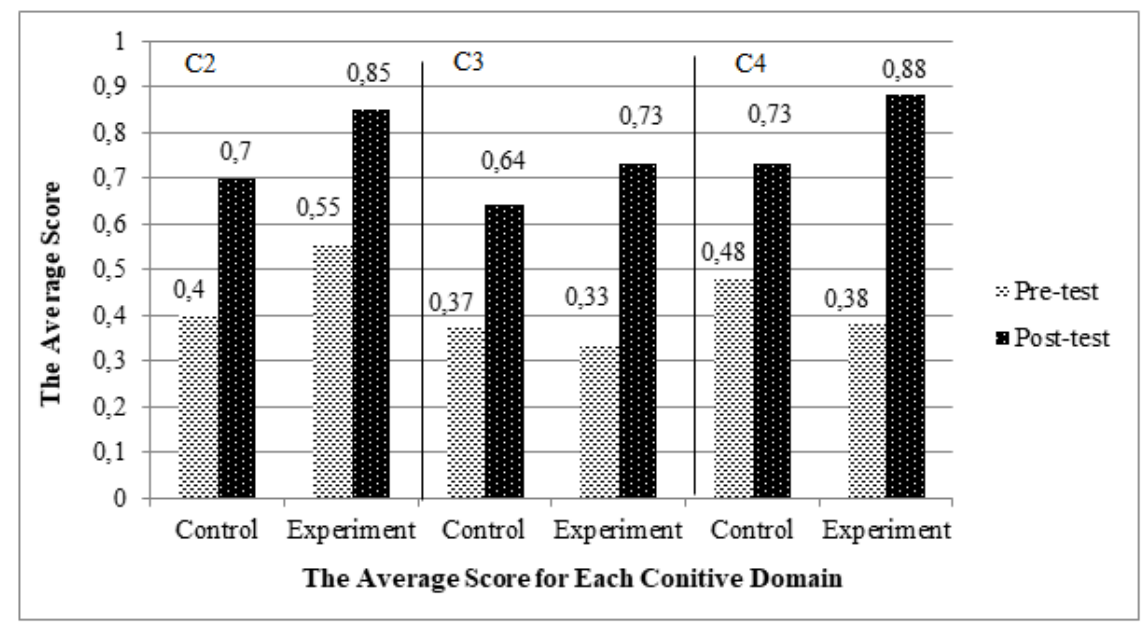

Figure 1 The Average Pre-test and Post-test Scores for Each Cognitive Domain

The final ability improvement in the experimental group that was given remedial teaching treatment using flipbook media was greater than the control group that was given remedial teaching treatment not using flipbook media. The use of flipbook media that facilitates visual students can maximize their ability to understand knowledge because learning is following their learning styles. During remedial teaching, visual students can learn according to their learning styles. Thomas stated that learning styles are important in increasing the 
understanding and achievement of each subject [16]. Flipbook media helps visual students' learning by looking at text; picture; and observing conceptual videos and animations related to phenomena in everyday life. Flipbook media helps visual students' in a) visualizing the phenomenon of parabolic motion in everyday life in the form of images, animations, and videos; b) explain the material and formulas in the form of text, animation, and video; c) visualize the motion movement path of the object after being given an initial angle through animation of the movement of the object in the parabolic path; d) predict the farthest distance on the path of objects with different angles through video showing the relationship between elevation angles and range distances; e) predicting the farthest distance on the path of objects with different initial speeds through video showing the relationship between initial velocity and range distance; f) predict the maximum height on the path of objects with different angles through video showing the relationship between elevation angles to maximum height; e) predict the maximum height on the trajectory of objects with varying initial speeds through video showing the relationship between initial speed and maximum height; and f) searching, analyzing, and transforming new information in accordance with what students want and can be happy to operate the media repeatedly in accordance with their ability to learn and understand teaching material that is in the media. But all that remains under the control of the teacher in the classroom [17].

In the cognitive domain C2 (understanding), flipbook media explain the concept of using visualization of text, images, animations, and videos of parabolic motion phenomena in daily life so that visual students of experimental groups more easily accept information based on what is displayed by the media. The material presented in the form of pictures, animations, and videos observed by students through flipbook media can facilitate and strengthen memory [18], also increase student curiosity and know the relationship of the phenomena presented with the material being studied [19].

In cognitive domain C3 (applying), flipbook media presents some animated formulas/equations in parabolic motion such as animated velocity equations on the $\mathrm{x}$-axis and $\mathrm{y}$-axis so that visual students in the experimental group can remember the formula more easily and more can answer questions to find the resultant velocity compared to visual students in the control group who saw the formula/equation only on the board and student textbooks.

In the cognitive domain C4 (analyzing), the flipbook media display animations and videos that make the visual students of the experimental group analyze material, that is visualized independently. Animation can show objects with ideas, explain difficult concepts, and explain abstract concepts into concrete [19], while video can describe the real state of a process, students can replay certain parts to see a more focused picture and the limitations of student memory can be overcome by repeated learning [20]. At the time of remedial teaching on visual students, the experimental group used flipbook media that can be used independently so that student-centered oriented learning and visual students can actively construct and deepen their knowledge so that their learning experiences are more students and can control their learning activities and can decide the extent of understanding [21]. Whereas visual students in the control group only accept explanations from the teacher, so that the teacheroriented learning is centered and it has limited understanding to the explanation given by the teacher.

The flipbook media have several characteristics, namely the learning process using a $5 \mathrm{M}$ scientific approach (observing, asking questions, gathering information, associating, communicating), implementing learning meaningfully, and practicing high-level thinking questions (ability C4 to C6) [22]. This is because the flipbook media present real objects, evokes the students' skills in asking questions, then there is information related to the material 
conveyed in the media through audio, video explanations, animations, text material, and practicum, then there are practice questions and evaluation questions that practice the ability of C4 (analyzing) that students can do through the flipbook media on the concept of parabolic motion [7].

The results of testing the hypothesis of this study are presented in Table 4 below.

Table 4. Hypothesis Test Results

\begin{tabular}{|c|c|c|c|c|c|}
\hline & \multirow{3}{*}{ Class } & \multirow{3}{*}{$\propto$} & \multicolumn{2}{|c|}{ Assumption test } & \multirow{2}{*}{$\begin{array}{c}\text { Hypothesis } \\
\text { test }\end{array}$} \\
\hline & & & Normality & Homogeneity & \\
\hline & & & Sig. Shapiro Wilk & Sig. Levene & Sig. (2-tailed) \\
\hline \multirow{2}{*}{ Pre-test } & Control & \multirow{4}{*}{0.05} & 0.775 & \multirow{2}{*}{0.77} & \multirow{2}{*}{0.728} \\
\hline & Experiment & & 0.328 & & \\
\hline \multirow{2}{*}{ Post-test } & Control & & 0.021 & \multirow{2}{*}{0.35} & \multirow{2}{*}{0.040} \\
\hline & Experiment & & 0.051 & & \\
\hline
\end{tabular}

\section{Conclusion}

The flipbook media on the concept of parabolic motion in remedial teaching affects visual students' learning outcomes. The post-test mean score of the experimental group (10.30) was higher than the control group (8.80). Improved visual students learning outcomes in the control and experimental groups are in the medium category. The $\mathrm{N}$-gain average of the experimental group was 0.3 greater than the control group. The improvement of student learning outcomes in the experimental group was the highest in the cognitive domain $\mathrm{C} 4$ (0.73) at the high category, in the cognitive domain C2 (0.60) was in the medium category, and the cognitive domain $\mathrm{C} 3(0.56)$ was in the medium category. The effectiveness of remedial teaching in the experimental group is in a very effective category $(80 \%)$. The flipbook media on the concept of parabolic motion is effectively used to improve student learning outcomes in remedial learning.

Acknowledgements We thank to the administration staff of physics education, supervisor lecturer at Syarif Hidaytullah State Islamic University Jakarta and students who have helped to finish this research.

\section{References}

[1] Kemendikbud, "Rekap Hasil Ujian Nasional (UN) Tingkat Sekolah," 2018. [Online]. Available: https://hasilun.puspendik.kemdikbud.go.id.

[2] Z. Zulfiani, I. P. Suwarna, and S. Miranto, "Science Education Adaptive Learning System As A Computer-Based Science Learning With Learning Style Variations.," J. Balt. Sci. Educ., 2018.

[3] D. Nurhayati, "Wawancara Penelitian pendahuluan," 2018.

[4] K. Direktorat Pembinaan SMA, "Petunjuk Teknis Pembelajaran Tuntas, Remedial, danPengayaan di SMA," 2010.

[5] I. P. Wicaksana, Adam; Suwarna, "Pengembangan Alat Peraga Pada Materi Gerak Parabola Untuk Melatih Keterampilan Proses Sains Siswa.” 2017.

[6] S. A. K. Marhadini, I. Akhlis, and I. Sumpono, "Pengembangan Media Pembelajaran Berbasis Android pada Materi Gerak Parabola untuk Siswa SMA," UPEJ Unnes Phys. Educ. J., vol. 6, no. 3, pp. 38-43, 2017. 
[7] A. F. Abdillah, "Pengembangan Media Pembelajaran Hypermedia Melalui 3D Flipbook untuk Meningkatkan High Order Thinking Skill pada Materi Gerak Parabola SMA.” Jakarta: FITK UIN Syarif Hidayatullah Jakarta, 2018.

[8] J. W. Creswell, "Understanding mixed methods research," Qual. Inq. Res. Des. Choos. Among Five Approaches, vol. 11, no. 2, pp. 1-19, 2007.

[9] N. D. Fleming, Teaching and learning styles: VARK strategies. IGI global, 2001.

[10] I. P. Suwarna, "Mengembangkan instrumen ujian komprehensif di program studi pendidikan fisika melalui Computer Based Test (CBT)," 2017.

[11] A. Field, Discovering statistics using IBM SPSS statistics. sage, 2013.

[12] D. E. Meltzer, "Addendum to : The relationship between mathematics preparation and conceptual learning gains in physics: a possible ' hidden variable' in diagnostic pretest scores," Am. J. Phys., vol. 12, pp. 1-6, 2002.

[13] R. R. Hake, "Analyzing change/gain scores," Unpubl. URL http//www. physics. indiana. edu/ sdi/AnalyzingChange-Gain. pdf, 1999.

[14] M. Weil, E. Calhoun, and B. Joyce, Models of teaching. Allyn and Bacon, 2000.

[15] H. Hafid, K. Kartono, and S. Suhito, "Remedial Teaching untuk Mengatasi Kesulitan Belajar Siswa pada Kemampuan Pemecahan Masalah Matematika berdasarkan Prosedur Newman," Unnes J. Math. Educ., vol. 5, no. 3, pp. 257-265, 2016.

[16] N. Othman and M. H. Amiruddin, "Different perspectives of learning styles from VARK model," Procedia-Social Behav. Sci., vol. 7, pp. 652-660, 2010.

[17] A. N. Deshpande, H. C. Pradhan, M. Sikdar, N. Deshpande, and K. Patel, "Learning Styles among Dental Undergraduates and Postgraduates-VARK Scale Study," Res. Rev. A J. Dent., vol. 9, no. 2, pp. 1-8, 2018.

[18] S. E. Smaldino, D. L. Lowther, C. D. Mims, and J. D. Russell, "Instructional Technology and Media for Learning." 2014.

[19] I. P. Arshela, Tri Nova; Suwarna, "Pengembangan Modul Elektronik 3d Pada Konsep Gelombang Bunyi Dan Cahaya Untuk Siswa SMA.” Fakultas Ilmu Tarbiyah dan Keguruan, 2017.

[20] R. Vebrianto and K. Osman, "The effect of multiple media instruction in improving students' science process skill and achievement," Procedia-Soc. Behav. Sci., vol. 15, pp. 346-350, 2011.

[21] H.-C. She and Y.-Z. Chen, "The impact of multimedia effect on science learning: Evidence from eye movements," Comput. Educ., vol. 53, no. 4, pp. 1297-1307, 2009.

[22] S. Andini, "Developing Flipbook Multimedia: The Achievement of Informal Deductive Thinking Level.," J. Math. Educ., vol. 9, no. 2, pp. 227-238, 2018. 